\title{
Using Graphic Organizers to Improve Reading Comprehension Skills for the Middle School ESL Students
}

\author{
Praveen Sam D ${ }^{1} \&$ Premalatha Rajan ${ }^{2}$ \\ ${ }^{1}$ Teaching Fellow \& Research Scholar, Dept. of English, Anna University, Tamil Nadu, India \\ ${ }^{2}$ Professor, Dept. of English, Anna University, Tamil Nadu, India \\ Correspondence: Praveen Sam D, Dept of English, Anna University Chennai, Sardar Patel Road, Guindy \\ Chennai 600025, Tamil Nadu, India. Tel: 989-456-6901. E-mail: praveen.samphd@gmail.com
}

\author{
Received: December 8, 2012 Accepted: December 27, 2012 Online Published: January 9, 2013 \\ doi:10.5539/elt.v6n2p155 URL: http://dx.doi.org/10.5539/elt.v6n2p155
}

\begin{abstract}
"A picture is worth a thousand words." In a modern-day classroom, students are surrounded by visual imagery through textbooks, notice boards, television, videos, or computers. Many middle school classrooms are filled with colorful pictures and photographs. However, it is unclear how - or if - these images impact the middle school ESL students who are developing reading comprehension. The focus of this article is on ESL middle school language learners' use of these graphics as information organizers while comprehending a passage for main ideas, supporting details, facts, opinions, comparisons and contradictions. This article also examines and proposes different forms of graphic organizers for achieving better understanding of texts. Differences in performance between the students who are exposed to the use of graphic organizers and the students who are not similarly exposed have been analyzed in this article. The experimental and control groups of this research are middle school students in ESL classes. The analytical method, ANOVA, is used to project the performance difference between the controlled and experimental groups. The result of the post-test suggested that the experimental group students have improved in all the five types of reading questions compared to controlled group students. Therefore, using graphic organizers is effective in reading questions like (1) identifying the main idea, (2) finding the supporting details, (3) dealing with vocabulary and (4) fact and opinion \& (5) making inferences. Furthermore, the pedagogical implication here is the use graphic organizers during reading comprehension sessions indirectly motivates the students to create their own graphic organizer for the passages they read and comprehend. This improves their creativity.
\end{abstract}

Keywords: visual imagery, reading comprehension, information organizers, main idea, supporting details, facts, opinions, comparisons, contradictions, middle school students, ESL classes

\section{Introduction}

Daniel Willingham (2008) classifies learners into three different types: Those who learn by looking, those who learn by listening, and those who learn by manipulating things - or visual, auditory, or kinesthetic learners. By understanding what sort of a learner a child is, teachers can optimize his or her learning by presenting material appropriate to him/her. Use of graphic organizers as visual tools for visual learners of comprehension will make comprehending a reading text and this makes comprehending easy and fun for students.

One of the first steps in this study was defining reading comprehension as the way students get the required information from a passage which has to be done as efficiently as possible. Osborne (2010) sees students' major reading problem arising when they are so worried about understanding every single word of a text they are reading that they do not get the general idea from the passage. Middle school ESL learners may also struggle in other areas while comprehending a passage. Firstly, while they may be good at recognizing and pronouncing the words, they struggle to understand the central theme of the passage. They read a passage in bits and pieces and fail to connect the ideas. This results in fragmentary understanding. Next, they fail to follow the schemata while reading. They fail to identify the main idea of a passage and how it is developed in the body paragraphs. Using a graphic organizer, they learn the skill of classifying information of a passage under a schema. Once they master this skill, they can divide the passage into different lexias such as main idea, supporting details, topic sentences, data, fact, opinion, etc. They elevate themselves from a stage of mere fragmentation to a stage of logical 
classification of information. This leads to a holistic comprehension of the passage, which in turn helps students decode the passage for its logical and linguistic signals.

While comprehending a passage, most ESL students mentally translate the content into their first language. Students may even respond to the comprehension questions through the time-consuming process of thinking in their first language and then translate it into English. Students cannot verify the accuracy of their translation of the meaning of the passage into their mother tongue. Using graphic organizers gives students alternatives to these inefficient methods of reading or comprehending a passage. In contrast to their usual approach to reading or comprehending a passage, they classify the content of the passage and then try to decode it. This paper explores how classifying a reading passage using graphic organizers has shown better results compared with reading a passage without using these organizers.

Tomlinson (1999) explains that teachers can modify three aspects of teaching: Content, Process, and Product. By using graphic organizers, teachers modify the product. It is a universal fact that students in a class are not likely to learn to read at the same rate. Some will learn faster than others, and some will be able to demonstrate their understanding in more complex ways sooner than others. For all children to learn at an optimal pace, teachers must match children with a reinforcing activity that allows each child to be successful in reading comprehension at a cognitively appropriate level. According to Kintsch and Rawson (2005), comprehension skills aided by graphic organizers help a reader develop his/her reading abilities. Therefore, incorporating graphic organizers in reading comprehension helps middle school ESL students in developing their comprehension skills.

Learning through visuals helps students in comprehending passages more effectively than other reading strategies like skimming, scanning, note making, etc. According to Slavin R. E. (2011), research in pedagogy and psychology demonstrates that visual learning is among the most effective methods for teaching comprehension skills to students of all ages. Helping students organize the content helps them better comprehend texts for information such as main ideas supporting details, facts, opinions, comparisons and contradictions.

According to Keene and Zimmerman (1997), students must be encouraged to make connections with the text they read to increase the effectiveness of reading. Graphic organizers can play a vital role establishing the connections. The text will be very clear to students when a graphic organizer is incorporated depicting the theme or content of a text they read. Moreover, graphic organizers using diagrams illustrate concepts and relationships between concepts discussed in a text.

Despite the appeal of using graphic organizers as a technique for assisting reading comprehension, critical response from research is mixed. Some research on graphic organizers has produced incongruent findings and has raised questions about their overall effectiveness in reading instruction (Jiang \& Grabe, 2007). Another issue relating to graphic organizers lies in the wide range of understandings of what a graphic organizer is and how it should be designed for research or instructional purposes.

\section{Discussions on Graphic Organizers}

A graphic organizer is a diagram that represents a relationship directed by a thinking-skill verb. The verb "sequence" calls for a diagram of a series of boxes connected by arrows that shows the "event" of one box leading to the "event" of another box (Hibbard, K. M. \& Wagner, E. A., 2003). In 1992, Jay McTighe in his book, Graphic Organizers: Collaborative Links to Better Thinking outlined three main ways teachers may use graphic organizers in their teaching and a number of ways that students can use them to aid their learning process. In the reading process, graphic organizers can be used at three levels: Before instruction, during instruction and after instruction. Before instruction, graphic organizers are used to understand the level of the students in terms of the content. During instruction, graphic organizers allow students to approach the content cognitively because they assist thinking. It also allows students to construct maps that are appropriate to their learning styles. After instruction, they help students as a summarization tool or technique and they help the students to understand their improvement in terms of understanding passage. If a student can connect prior knowledge with what was learned and identify relationships between those ideas, it means graphic organizers have successfully assisted them in the course of their learning process.

The strategy that has received the most attention from the research community is the graphic organizer (Barron, 1969). Graphic organizers are representations, pictures or models used for processing textual information. They facilitate understanding of knowledge when there is a large amount of information to work with, in a given limited time (Liliana, 2009). There are various functions of graphic organizers. In reading comprehension, they assist learners to:

- Clarify and organize information into categories (main idea, supporting details, topic sentence, facts, 
opinion, etc)

- Organize information in a paragraph for better understanding

- Construct meaning of difficult words and sentence dividing into lexias

- Understand the context by associating with prior knowledge

- Identify conceptual and perceptual errors that may occur in the course of reading a passage

Graphic organizers can have various forms, from representations of objects to hierarchical and cyclical structures. Although their use in learning activities is preferred by people who have a visual style of learning, graphic organizers are extremely useful to different learners (Liliana, 2009). Semantic map, structured overview, web, concept map, semantic organizer, story map, graphic organizer, etc. no matter what the special name, a graphic organizer is a VISUAL representation of knowledge. It is a way of structuring information, of arranging important aspects of a concept or topic into a pattern using labels (Bromley, Irwin-DeVitis, \& Modlo, 1995).

Graphic organizers have been classified into five major categories according to their structures: "star web, chart matrix, tree map, chain, and sketch. Graphic organizers have also been classified into eight categories according to their purposes for learning (Loretta F, 2008). The eight categories of graphic organizer are KWL chart, history frames, word map, zooming in and zooming out - concepts, zooming in and zooming out -people, Inquiry chart, venn diagram, column notes. KWL charts can be used as a teacher-led activity to introduce a new topic at any grade level. A history frame allows students to look at historical events and break the information down to understand its significance, the people and places involved and any other pertinent information. A word map helps students analyze a new or complex vocabulary word from many different angles. Zooming in and out - concept graphic organizer allows students to delve deeper into a more complex concept. There is a box in the middle of the page for the concept; then there are five other boxes branching out from the middle, and zooming in and out organizer is similar to the one for concepts, but focuses on people instead. The center box is for the name of a person and the surrounding boxes include spaces for the most and least important information, similar people, related events, surprising facts and a summary statement. An inquiry chart or I-chart is a way to organize information obtained during research. It contains four columns across the top, each for a different question. A Venn diagram is used to compare two ideas, events or people. It contains two overlapping circles. A column notes organizer is simple to set up and versatile in its applications. To organize notes, all a student needs to do is divide a piece of paper into two sections, each with its own heading.

According to the report of North Carolina Regional Education Laboratory, 1988 examples of reading strategies used with specific graphic organizers include: K-W-L-H technique, anticipation and reaction guide, spider map, series of events chain, continuum scale, network tree, human interaction outline, compare \& contrast matrix, problem and solution outline, fishbone map, and cycle. Graphic organizers have been categorized by both structure and function. The structure category contains "Webbing, Concept Mapping, Matrix, Flow Chart," whereas the function category consists of "Describing, Comparing \& Contrasting, Classifying, Sequencing, Causal, Decision Making” (Loretta F, 2008).

Graphic organizers provide teachers with tools to help students on the road to higher achievement in their reading comprehension skills. Graphic organizers that target critical and creative thinking elements help develop students in their ability to comprehend and understand the meaning of a text. The focus of the students in content is improved and they can classify the content into small understandable units. Graphic organizers provide new language that facilitates classroom communication, as well as deepen understanding of the content that teachers work to transmit. The effectiveness of graphic organizers is proved in the analysis done by Marzano, Pickering, and Pollock (2001).

Graphic organizers are effective strategies to promote reading comprehension. The National Reading Panel (220) cited graphic organizers as one type of instructional strategy that is effective in the improvement of reading instruction. Graphic organizers can also be used effectively during reading to check ongoing comprehension. Likewise, they can be used as a summative activity to assess comprehension once students are done with reading the text. It can also be used to review vocabulary in various content areas.

According to Barron (1979), graphic organizers are effective in reading comprehension whereas, providing students with readymade graphic organizer will not motivate them. Readymade graphic organizers will be viewed by them as another template were they have to fill in with information. Therefore, when students come out with their own organizers, they develop their thinking skills. If teachers can avoid providing students with readymade graphic organizers, students would motivate themselves by designing their own graphic organizers.

Another important feature of a graphic organizer is that it can be designed to match specific objectives with a 
text. In Figures 1.1 to 1.4 , examples of some graphic organizers that are used for interpreting a text with a specific objective are shown. Figure 1.1 is a graphic organizer that could be used to classify the author's purpose in a reading comprehension passage. This could be further developed based on the requirements for different passages. Figure 1.2 is a graphic organizer that could be used to classify the main idea and supporting details in a passage. Figure $1.3 \& 1.4$ are graphic organizers that could be used for classifying information in a passage as fact or opinion and comparison or contrasting respectively.

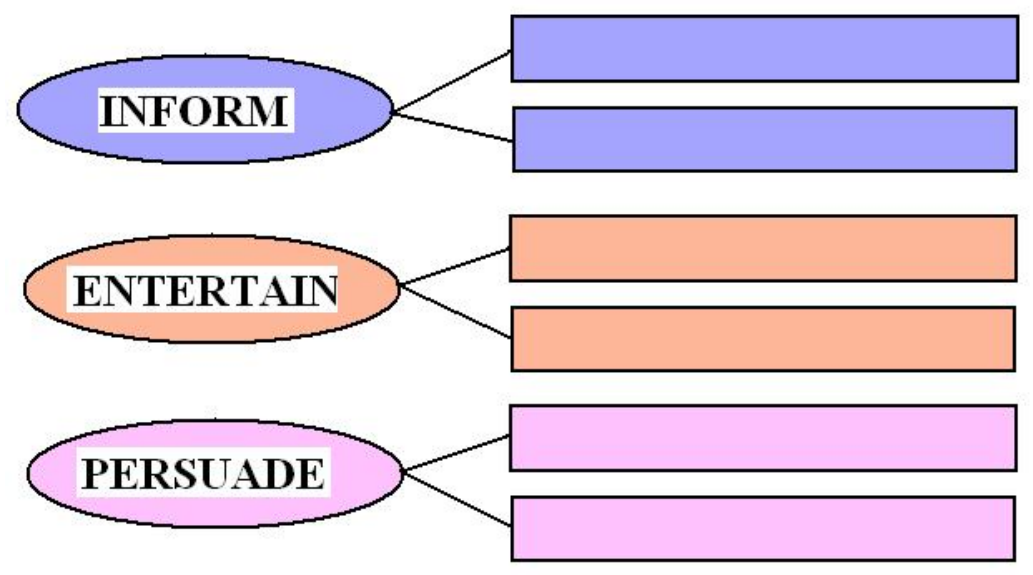

Figure 1. Author's purpose

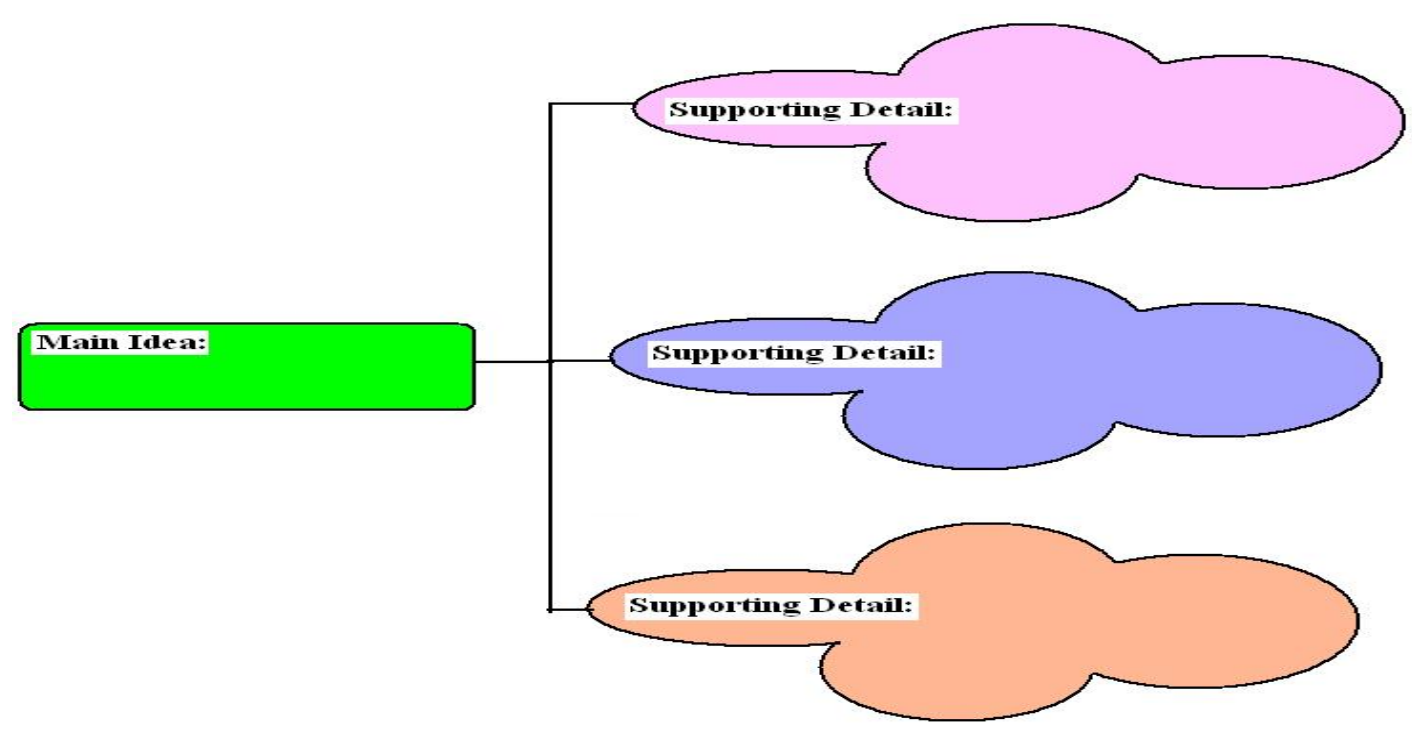

Figure 2. Main Idea \& Supporting Details 


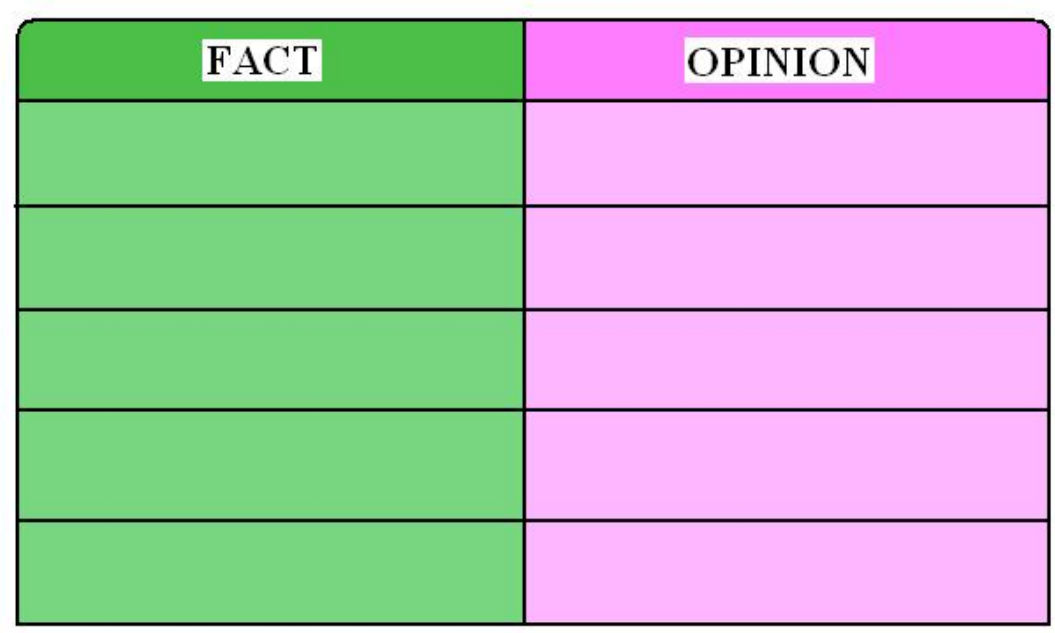

Figure 3. Fact and Opinion

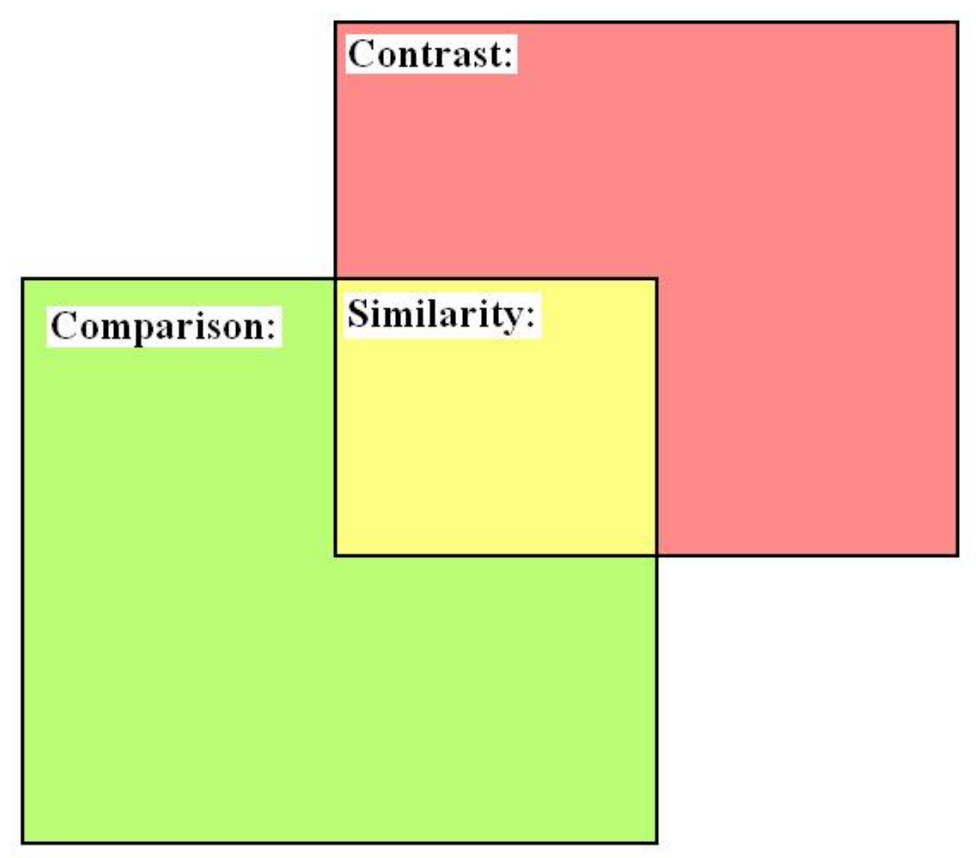

Figure 4. Compare and Contrast

Note: Different types of graphic organizer that could be used in classrooms are available at

- http://tri-valley.k12.sd.us/tech_department/graphic_organizers.htm

The following links consist of videos that help teacher and student to design their own graphic organizers suiting specific learning objectives:

- $\quad$ www.youtube.com/watch? $\mathrm{v}=31$ i6y $9 \operatorname{cbf} 98$

- $h t t p: / / w a t c h k n o w l e a r n . o r g / C a t e g o r y . a s p x ? C a t e g o r y I D=3129$

- http://technology4kids.pbworks.com/w/page/33346396/graphicorganizers

Such graphic organizers are simple and easy to construct. Students need not always depend on an existing graphic organizer, but they can come up with their designs that could help in understanding various aspects of a 
text. The goal of such simple graphic organizers is to allow students the opportunities to work with recurring patterns that are easily recognized and readily used (Jiang \& William, 2007).

The graphic organizer serves the same function as a visual aid that defines hierarchical relationships among concepts (Readence, Bean, \& Baldwin, 2004). They are being used successfully in different educational settings. Compared with self-study, graphic organizers helped regular education students, remedial students, and students with learning disabilities perform significantly improve their performance in the subject areas of science, health, and social studies (Horton, Lovitt, \& Bergerud, 1990).

\section{Literature Review on the Use of Graphic Organizer in Reading Comprehension}

In the past decade, a great deal of research has been done on using Graphic Organizers in effectively arranging the content of a passage and decoding its meaning. Ciascai (2009) investigated Graphic Organizers as 'instruments of representation, illustration and modeling of information'. Her investigation also examined the use of graphic organizers in educational practice for building and systematizing knowledge. This investigation concluded that graphic organizers help learners in understanding the content of the text by classifying and modeling ideas in the text (Ciascai, 2009).

Barron and Stone (1974) analyzed the learning of vocabulary relationships in a reading text. In one experiment, they randomly assigned students to one of three groups graphic advance organizer (GAO), graphic post organizer (GPO), or control (C). The dependent variable was a vocabulary relationship test (VRT) based on the content structure of the passage. The task assigned to students was to identify which of the four terms given were unrelated. Two comparisons were undertaken in the analysis. The first contrasted achievement on the VRT in the GAO and GPO groups and yielded a statistically significant difference in favor of the GPO condition. The second comparison contrasted the performance of the GAO and control groups on the VRT and yielded no statistically significant difference. Although the findings appeared to support the facilitative effects of the GPO, the study had a fundamental methodological confound. Two variables, position of the graphic organizer (pre-test or post-test) and teacher versus student construction, were manipulated simultaneously in the study (Griffin, Cynthia C., Linda Duncan Malone \& Edward J. Kameenui 1995).

Simmons (1988) investigated how the use of graphic organizers reflected a passage's hierarchy of information - as organized through topic sentences supporting details, etc. - and found that students had no problem in identifying the main idea of a passage and the supporting details and their organization in each paragraph. This helped the students in understanding the passage as a whole, and they could also understand the structure of each paragraph. According to the study, EFL students who were trained in using graphic organizer performed better in the post test compared to the students who did not use graphic organizers.

Griffin and Tulbert (1995) investigated the types of Graphic Organizers that are most effective for L1 students in reading expository texts. Almost all the GO studies have been carried out with L1 readers. As L2 students come into contact with more dense and complex reading materials, they need special scaffolding devices to facilitate their reading comprehension (Jiang, X. \& William G, 2007). It is important to know if Graphic Organizers serve this purpose. Forms of graphic Organizers have ranged from hierarchical listings of vocabulary terms to elaborate visual-spatial displays with accompanying descriptors and phrases (Griffin \& Tulbert, 1995).

Williams et al. (2005) studied that incorporation of graphic organizer in the comprehension of expository reading texts. This study investigates the effectiveness of an instructional program designed to teach $2^{\text {nd }}$ graders how to comprehend compare-contrast expository text. Along with introducing new content (animal classification), the program emphasizes text structure using a graphic organizer, and through the close analysis of specially constructed exercise paragraphs. Students were able to demonstrate transfer to uninstructed compare-contrast texts though not to text structures other than compare-contrast. Moreover, the text structure instruction did not detract from their ability to learn new content. The results provide evidence that explicit instruction in comprehension is feasible and effective as early as the $2^{\text {nd }}$ grade.

Xiangying Jiang and William Grabe, (2007) have researched a number of generic forms of graphic representations such as definitions, compare and contrast, cause and effect, process and sequence, etc that apply to regularly recurring text structures. Outcomes of this review included a focus on graphic organizers that more closely reflect the discourse organization of the text, leading to more consistent representation of major text structures.

Based on the literature survey on using graphic organizer in reading comprehension amongst ESL students, it is understood that the need for graphic organizer in reading comprehension among ESL students is not adequately researched. 


\section{Awareness of Text Organization}

Reading is an important language skill and the process of reading is developed using many strategies. The understanding of reading material is based on how readers approach it and how the content is handled while being read. More specifically, awareness of how texts are organized is seen as an important part of a reader's overall comprehension abilities (Pearson \& Fielding, 1991; Trabasso \& Bouchard, 2002). Students can be trained to recognize discourse structuring in texts through the use of graphic organizers - visual representation of information in the text (Jiang \& William Grabe, 2007). Graphic organizers need not be complicated; rather they need to be simple and assist the students in understanding a concept clearly. The source of such organizers is wide, but it will be effective if teachers prepare their own organizers. It is intuitively appealing to use various graphic organizers as a tool for facilitating reading comprehension. Researchers have proved that students' reading and understanding abilities are increased with the use of visuals. When the content is arranged in a graphic organizer, the students (middle school level) are automatically attracted towards it. While content is organized in a graphic organizer, decoding the meaning of the content becomes an interesting job for the students compared to the skimming or scanning of the content. From implementations of the various Graphic Organizer methodologies proposed, a body of empirical research has provided preliminary but inconclusive findings of the facilitative effect of Graphic Organizers on students' comprehension and retention of information from expository texts (Jiang \& William Grabe, 2007).

Graphic organizers are excellent for teaching students about relationships in a text. They help break down the whole text into manageable pieces. They also show the relationship of those pieces to each other. As mentioned earlier, there are many graphic organizers available to be used with a variety of texts. At the middle school level, most graphic organizers would be filled out together as a class. Teachers can either reproduce the graphic organizers on an overhead transparency sheets or projectors. By participating in the process of completing a graphic organizer, students are deepening their understanding of the text, as well as receiving guided practice both in how to complete graphic organizers and how to use them to increase comprehension (Smith, Jodene Lynn, 2010). The following is a paragraph on Cigarette Smoking and the paragraph is comprehended using a graphic organizer.

Sample Paragraph 1:

The well established dangerous effects of tobacco smoking such as lung cancer, heart disease, and emphysema-bronchitis are familiar to many of us. Cigarette smoking has probably caused more bodily harm than all the wars of recorded history combined. The yearly death rate of lung cancer alone is over 80,000 in the United States. The major cause of lung cancer is cigarette smoking. It has been estimated that during the past ten years cigarette smoking was a causative factor in the deaths of at least 2 million Americans and countless numbers of people in other countries where cigarette smoking is commonplace. Statistics taken in 1992 determined that $20 \%$ of all deaths in the world occur due to smoking. Smoking is still on the rise in the developing world but falling in developed nations. About 15 billion cigarettes are sold daily - or 10 million every minute according to 2002 WHO data. The rate of smoking amongst women and people from Asian countries has risen steadily in recent years. It has not merely reached epidemic proportions; it has become a scourge, a health disaster unparalleled in the history of the world. (Source:http://books.google.co.in/books?id=h5QnGCpmhgUC\&printsec=frontcover\#v=onepage\&q\&f=false) 


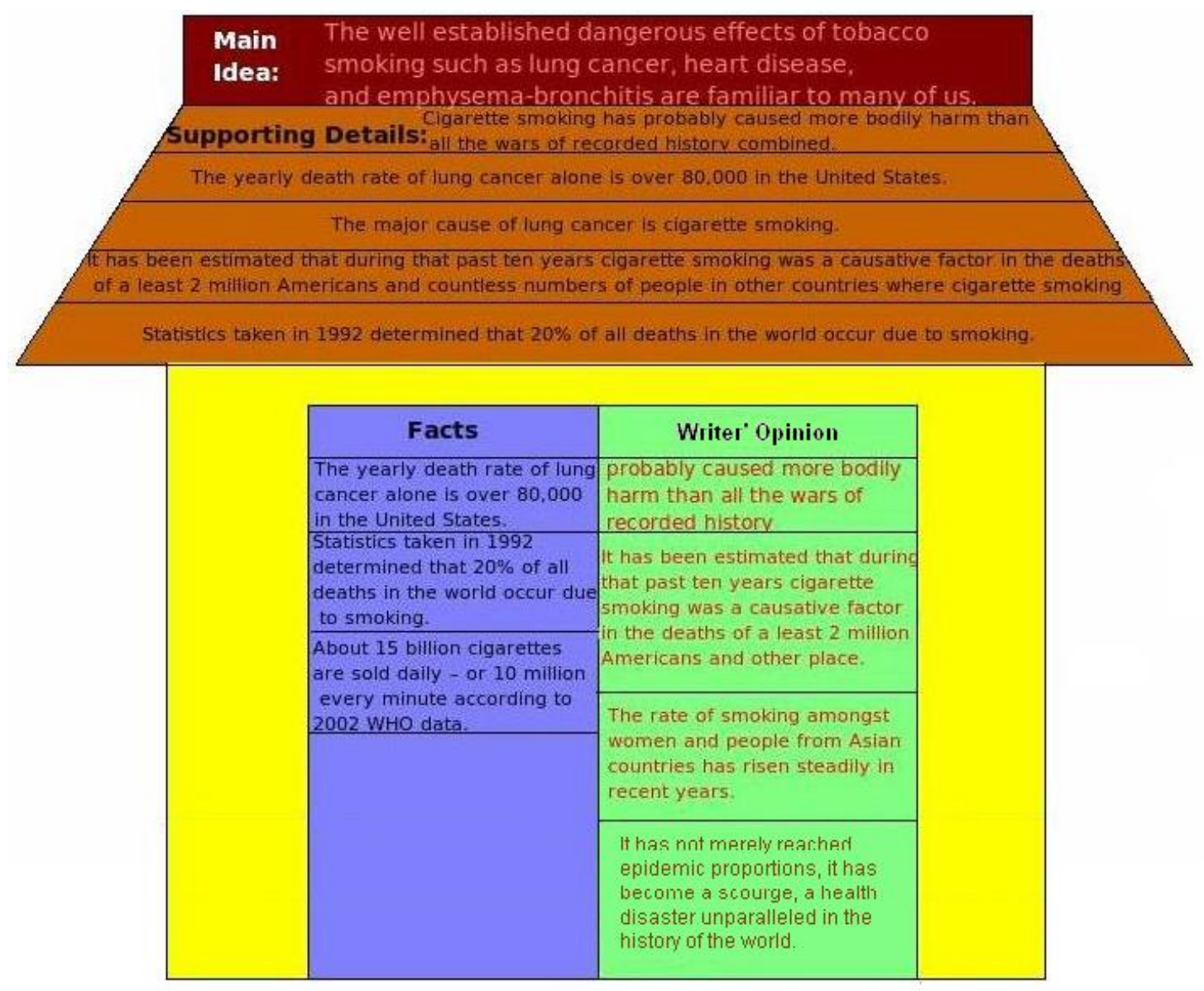

Figure 5. Graphical Representation of the Information in the Sample Paragraph 1

These graphic organizers are commonly used in the EFL classrooms, whereas most of the ESL students are not motivated to use these organizers while reading comprehension sessions. Various ways to utilize graphic organizers by both EFL and ESL reading researchers are being researched. Compared to standardized reading measures, researcher-developed comprehension measures were associated with higher effect sizes (Kim, A. H., Vaughn, S., Wanzek, J., \& Wei, S., 2004).

According to the study of Simmons (1988), the use of graphic organizers reflected the hierarchy of information within a passage like topic sentence, supporting details, etc. Students were comfortable in identifying the main idea of a passage and the supporting details and their organization in each paragraph. This helped the students in understanding the passage as a whole, and they could also understand the structure of each paragraph.

\section{An Experimental Study on the Effectiveness of using Graphic Organizers in Reading Comprehensions}

\subsection{Participants}

This study was carried out at a school in the western part of Tamil Nadu, India. This is a school where English is being taught as a second language. In this school, the middle school students are being taught reading skills to facilitate their reading. Class eight students were classified into two sections (Section A and Section B) in the school. One of the sections was assigned as a control group with the traditional reading approach, while the other section was the experimental trained with using graphic organizers to decode information from reading passages.

The intervention lasted for two weeks. The number of students in the classes was thirty five each. During the experiment, students from each class were trained in reading comprehension. They were classified as group A and Group B. Students of group A were trained in reading comprehension in the traditional ways like making the students read the passage again and again, read the passage after reading the comprehension questions, etc. whereas, group B were trained using graphic organizers in comprehending passages. 


\subsection{Reading Materials}

The reading materials used in the present study consisted of selected texts from a supplementary reader designed and published by the Tamil Nadu Textbook Corporation. This reader consisted of both expository and narrative texts for the middle school ESL students. The selection of the reading material was based on the following parameters: (a) Complexity level (b) Variety of topics and (c) Lexical count.

\subsection{Instructional Procedure}

\subsubsection{The Experimental Group}

At the beginning of the instruction, the researcher familiarized the students with what graphic organizers are and how to use them effectively while reading a text. The students were also trained to use different organizers for different types of passages. The students learned a variety of existing graphic organizers and they also started creating their own organizers. They used these graphic organizers at all the three levels - before instruction, during instruction and after instruction.

\subsubsection{The Control Group}

The instruction material and content provided for both the experimental and control groups were the same but the control group was not exposed to the use of graphic organizers and implementing the same in reading process. The control group adopted traditional methods where students were made to read the passage again and again to understand the content and answer the comprehension questions. They were able to understand the meaning conveyed in the paragraph or passage but they could not classify a paragraph into main idea, topic sentence, supporting details, etc.

\subsubsection{The Pre-test and Post-test Model}

All true experiments have a post-test - that is, measurement of the outcome in both groups after the experimental groups have received the treatment. Many true experiments also have pre-tests, which measure the dependent variable prior to the experimental intervention (Rafael \& Russell, 2005). A pre--test was administered to both experiment and control groups to ascertain the standard of the students in reading comprehension. The pre-test scores of both the groups were recorded. The test material was designed based on the scope of the study. It was made up of 2 passages, totaling 20 questions which can be classified into five types of reading questions - (1) Identifying the main idea, (2) finding the supporting details, (3) understanding vocabulary, (4) distinguishing fact from opinion and (5) making inferences. Out of 20 questions, there were 4 main idea questions, 4 supporting detail questions, 4 vocabulary questions, 4 fact and opinion questions and 4 inference questions. Each question was worth 1 mark and the sum total of the test was 20 which was calculated over 100 marks.

Before administering the pre-test, it was important for the researcher to examine whether the proficiency level of the students in both the experimental and controlled groups are the same or different. In the first session of the experiment, a pre-test was given to all the participants in the two groups. The result of the pre-test proved that the comprehension skills of both the groups were on the same level. Table 1 shows the Statistical Results of Pre-Test based on One-Way ANOVA on Types of Comprehension Questions.

Table 1. Statistical Results of Pre-Test for One-Way ANOVA on Types of Comprehension Questions

\begin{tabular}{|c|c|c|c|c|c|c|c|}
\hline S.No & $\begin{array}{l}\text { Types } \\
\text { Questions }\end{array}$ & & Sum of the squares & df & $\begin{array}{l}\text { Mean } \\
\text { Square }\end{array}$ & $\mathbf{F}$ & Sig. \\
\hline \multirow[t]{3}{*}{1} & Identifying the & Between Groups & 0.229 & 1 & 0.229 & 0.3931 & 0.86 \\
\hline & Main Idea & Within Groups & 39.543 & 68 & 0.582 & & \\
\hline & & Total & 39.771 & 69 & & & \\
\hline \multirow[t]{3}{*}{2} & Finding & Between Groups & 0.014 & 1 & 0.014 & 0.0190 & 0.99 \\
\hline & Supporting & Within Groups & 51.257 & 68 & 0.754 & & \\
\hline & Details & Total & 51.2571 & 69 & & & \\
\hline \multirow[t]{3}{*}{3} & Understanding & Between Groups & 0.014 & 1 & 0.014 & 0.0272 & 0.98 \\
\hline & Vocabulary & Within Groups & 35.771 & 68 & 0.526 & & \\
\hline & & Total & 35.786 & 69 & & & \\
\hline \multirow[t]{3}{*}{4} & Distinguishing & Between Groups & 0.129 & 1 & 0.129 & 0.1937 & 0.93 \\
\hline & Fact form & Within Groups & 45.143 & 68 & 0.664 & & \\
\hline & Opinion & Total & 45.271 & 69 & & & \\
\hline \multirow[t]{3}{*}{5} & Making & Between Groups & 0.357 & 1 & 0.357 & 0.8350 & 0.73 \\
\hline & Inferences & Within Groups & 29.086 & 68 & 0.428 & & \\
\hline & & Total & 29.443 & 69 & & & \\
\hline
\end{tabular}


According to Prof. R.A. Fisher, originator of ANOVA, "Analysis Of Variance (ANOVA) is the separation of variances ascribable to one group of process from the variance ascribable to the other group". From the One Way Analysis of Variance it is understood that there are significant changes between the pre-test and the post-test. The $2^{\text {nd }}$ column in the above ANOVA table titled as 'Types of Questions' and the fourth column gives the value of sum of squares between and within the controlled group and experimental group. The next column, the 'Degrees of Freedom' is the number of data considered. The 'Mean Square' column is obviously the ratio between the $4^{\text {th }}$ and $5^{\text {th }}$ columns. The last two columns are the final calculations of $\mathrm{F}$ ratio and the significance between the two groups.

The set of graphs given below shows the performance of the students in each type of questions in the pre-test identifying the main idea, finding the supporting details, vocabulary, fact and opinion, making inferences).

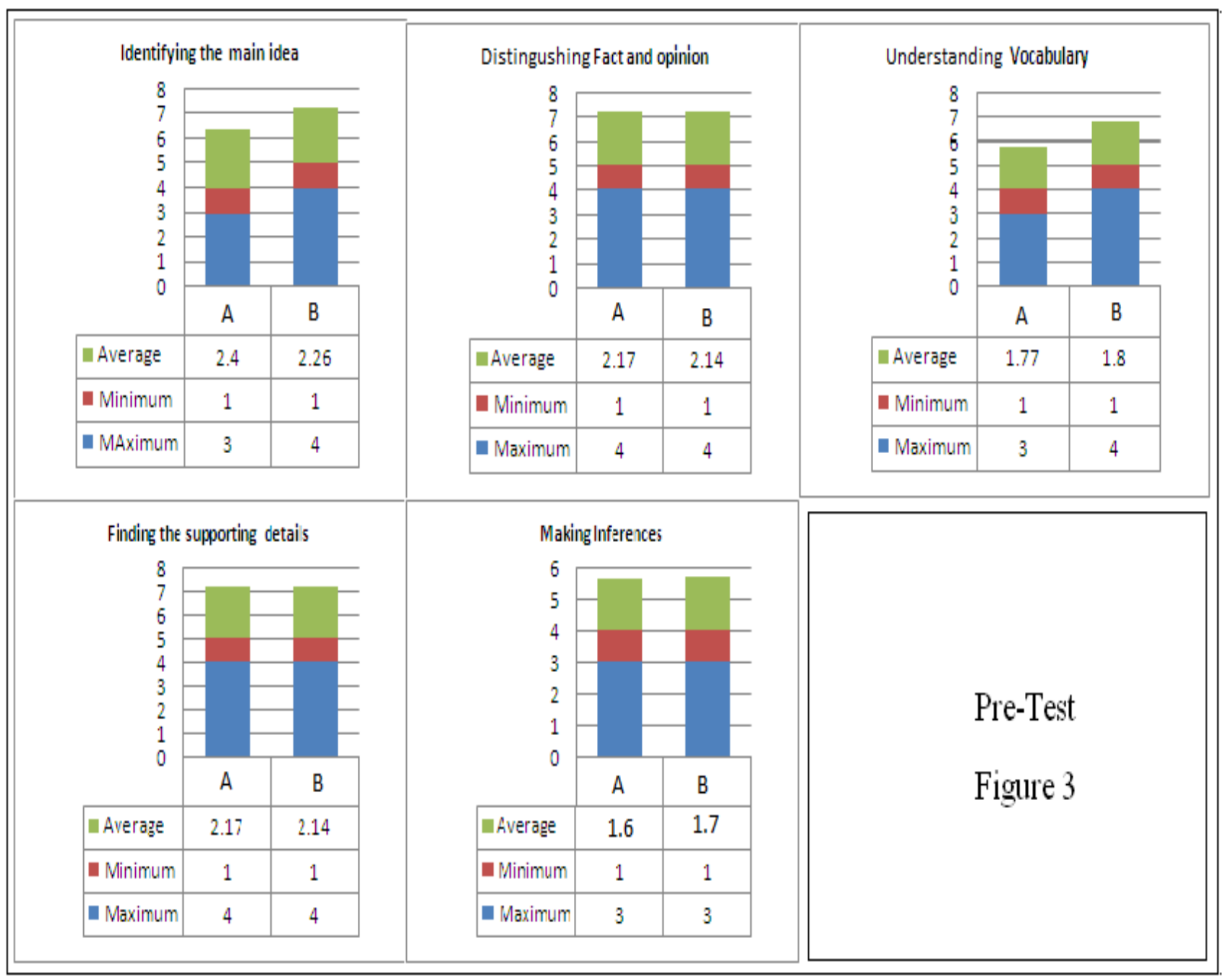

Figure 3. Graphical Representation of the Performance of the Students in the Pre-Test

Table 1 shows that there is no significant difference on the pre-test with regard to five types of comprehension questions between the control and experimental groups. For data analysis, the statistical test of One-Way ANOVA was applied to investigate the effect of using graphic organizers on the specific types of reading comprehension questions.

\section{Result}

This study discusses the effect of using graphic organizers on the EFL learners' answers to different types of comprehension questions. An analysis of variance (One-Way ANOVA) was performed to evaluate the impact of the two instructional approaches - Using Graphic Organizer and the traditional comprehension method - on all participants' answers to five types of comprehension questions. 
Table 2 demonstrates the results of post-test for One-Way ANOVA on types of comprehension questions between the two groups after the 2 weeks' training.

Table 2. Statistical Results of Post-Test for One-Way ANOVA on Types of Comprehension Questions

\begin{tabular}{|c|c|c|c|c|c|c|c|}
\hline S.No & Types of Questions & & $\begin{array}{l}\text { Sum of the } \\
\text { squares }\end{array}$ & df & $\begin{array}{l}\text { Mean } \\
\text { Square }\end{array}$ & $\mathbf{F}$ & Sig. \\
\hline \multirow[t]{3}{*}{1} & Identifying the Main & Between Groups & 17.500 & 1 & 17.500 & 25.86 & 0.19 \\
\hline & Idea & Within Groups & 46.000 & 68 & 0.676 & & \\
\hline & & Total & 63.500 & 69 & & & \\
\hline \multirow[t]{3}{*}{2} & Finding the & Between Groups & 15.557 & 1 & 15.557 & 24.1055 & 0.19 \\
\hline & Supporting Details & Within Groups & 43.886 & 68 & 0.645 & & \\
\hline & & Total & 59.443 & 69 & & & \\
\hline \multirow[t]{3}{*}{3} & Vocabulary & Between Groups & 14.629 & 1 & 14.629 & 26.0599 & 0.19 \\
\hline & & Within Groups & 38.171 & 68 & 0.561 & & \\
\hline & & Total & 52.800 & 69 & & & \\
\hline \multirow[t]{3}{*}{4} & Fact and Opinion & Between Groups & 14.629 & 1 & 14.629 & 24.7624 & 0.19 \\
\hline & & Within Groups & 40.171 & 68 & 0.591 & & \\
\hline & & Total & 51.800 & 69 & & & \\
\hline \multirow[t]{3}{*}{5} & Making Inferences & Between Groups & 10.414 & 1 & 10.414 & 14.5800 & 0.19 \\
\hline & & Within Groups & 48.571 & 68 & 0.714 & & \\
\hline & & Total & 58.986 & 69 & & & \\
\hline
\end{tabular}

The average pre-test score for both the groups (Controlled group and Experimental group) was $50 \%$ i.e. 10 out of 20 marks, and the average post-test score for both the groups was $52.6 \%$, i.e. 10.5 out of 20 marks.

When comparing pre-test and post-test scores for the whole group ( $\mathrm{N}=70)$, the average pre-test $\%$ was 39 and the average post-test $\%$ was 47 , yielding a $\%$ difference of +8 . This positive increase shows that the difference in percentage is statistically significant. When an ANOVA was performed, the pre-test and post-test scores of the students were significantly different. The variance ratio for the pre-test was between 0.02 and 0.08 whereas, the post test ratio was in between 14 and 26 which shows that there is a considerable improvement in the post test for the second set of data, i.e. the experimental group at 0.01 level $\left(F_{\alpha}=.01\right)$. Further, the results yield significance at the .001 level- meaning that for the whole group, the difference between the pre-test average score and the post-test average score is statistically significant.

The average pre-test score for the group A is $38 \%$ while the same group got an average $\%$ of 39.2 during the post-test. This proves there is no significant improvement in the controlled group. But the case was different with the Experimental group. This group got an average \% of 39.43 in the pre-test and $56.23 \%$ in the post test, which means the group has improved significantly. The improvement is $+17 \%$. This shows the group has improved more than $10 \%$ which is significant. This can be seen from the ANOVA Table 1 and Table 2. The mean sum of squares has increased in all types of questions. This can be seen from the data of 'between groups'. In identifying the main idea the pretest sum of squares is 0.3 and 17.5 in the post test with an increment of 17.2. In finding the supporting details the pretest mean sum of squares is 0.1 and 15 in the post-test with an increment of 14.9. For the third type of Question (Vocabulary), the pre-test mean sum of squares is 0.05 and 14.1 in the post-test with an approximate increment of 14. For fact and opinion questions the pre-test sum of squares is 0.2 and 14 in the post test with an increment of 13.8. For questions pertaining to Making Inferences, the improvement was also considerable. The data gave the sum of squares as 0.45 in the pre-test and 10 in the post-test. Hence, we can conclude that using graphic organizers while reading helps the students very much to understand the above reading strategies while comprehending a passage.

The set of graphs below shows the performance of the students in each type of questions in the pre-test (Identifying the Main Idea, Finding the Supporting Details, Vocabulary, Fact and Opinion, Making Inferences). 


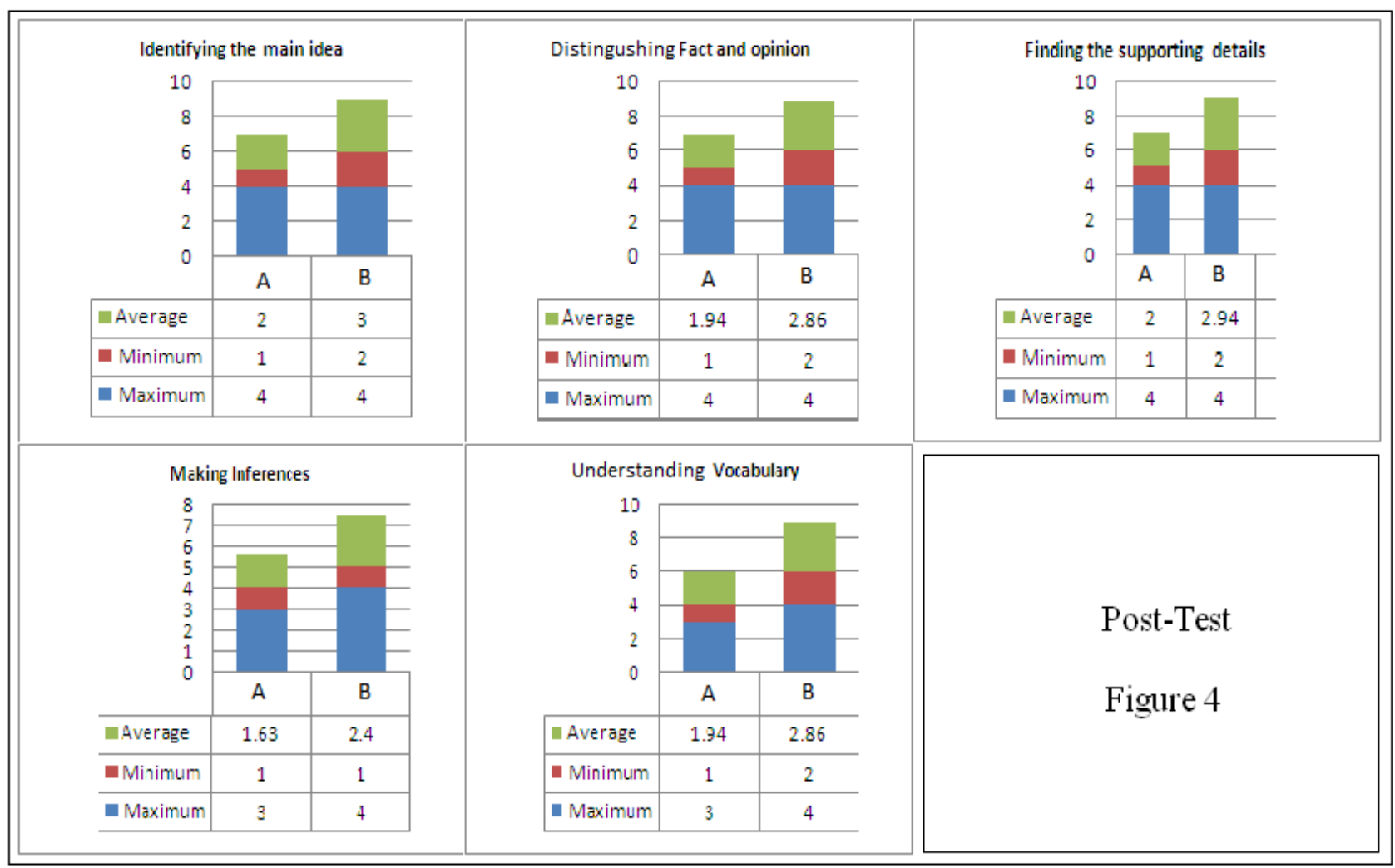

Figure 4. Graphical Representation of the Performance of the Students in the Post-Test

Although graphic organizers have been strongly recommended and widely practiced by reading experts and classroom instructors, more consistent definitions and procedural descriptions of graphic organizers are essential. In spite of effective implementation, not all of them have facilitated reading comprehension (Xiangying Jiang, \& $\mathrm{d}$ William Grabe, 2007).

From this study, it is understood that using graphic organizers is an effective tool. The result of the post-test shows that the experimental group students have improved in all the five types of reading questions compared to controlled group students. Therefore, using graphic organizers is effective in reading questions like (1) identifying the main idea, (2) finding the supporting details, (3) dealing with vocabulary and (4) fact and opinion \& (5) making inferences.

\section{Pedagogical Implications}

According to Jiang (2012), discourse structure awareness plays a vital role in reading comprehensions in the L1 and the L2 contexts. Therefore, pedagogical efforts should be made to raise students' awareness of a reading text. Graphic organizers play an important role in representing the text structure from a mere text to content suitable for discussion in classroom instructions. Graphic organizers depict the discourse structure by representing the interrelationship among ideas and patterns of the text (Jiang, X., 2012).

In a classroom, participation of the students in the learning process is one of the very important parameters. To achieve active involvement, classroom activities must be task-oriented and engaging (Jiang, X., 2012). The use of graphic organizer helps the teachers in hooking the students towards the reading comprehension passage. The students find it more interesting to work on a graphic organizer and fill it with information collected from the comprehension passage. Here, filling in the graphic organizers makes it a task-oriented session.

When teachers use graphic organizers to teach, it indirectly motivates the students to create their own graphic organizer for the passages they read and comprehend. This improves their creativity.

\section{Conclusion}

This paper has shed some light on the impact of using graphic organizers on Indian Middle School students' answers on five different types of comprehension questions categorized in the pre-test and post-test model. The 
findings of the study offer some pedagogical implications for middle school reading instruction in ESL contexts. First, the use of graphic organizers by ESL learners significantly promoted:

(i) Strategic reading competence

(ii) Classification or graphical arrangement the content of a passage

(iii) Distinguishing the most salient ideas from the supporting information.

Second, in comparison with the traditional reading approach, using graphic organizers offers:

(i) More chances for school learners to participate more actively in constructing organizers

(ii) A way to get the meaning of the passage

Moreover, this result was parallel with the observations by Koda. K (2007) that is the goal of reading is to construct text meaning based on visually decoded information. Graphic Organizers help readers in identifying the required information from the material, classifying or arranging them in templates which are creatively constructed by the readers themselves and they also guide readers in drafting similar information in a different context. However, more research studies with ESL readers should be executed to further investigate the effectiveness of graphic organizers on L2 reading comprehension. Based on this study, it is suggested to use graphic organizers in L2 reading classroom for better learning process and better output.

\section{Reference}

Barron, R. F. (1969). The use of vocabulary as an advance organizer. In Research in reading in the content areas: First year report. In H. L. Herber, \& P. L. Sanders (Eds.), Syracuse. NY: Syracuse University, Reading and Language Arts Center.

Bromley, K., Irwin-DeVitis, \& Modlo, M. (1995). Graphic Organizers. New York: Scholastic Professional Books.

Chi Fan, Y. (2010). The Effect of Comprehension Strategy Instruction on EFL Learners' Reading Comprehension. Asian Social Science, 6(8), 19-29. http://dx.doi.org/10.5539/ass.v6n8P19

Ciascai, L. (2009). Using Graphic Organizers in Intercultural Education. Acta Didactica Nepocensia, 2(1), 9-18.

Cunningham, A., \& Shagoury, R. (2006). Starting with Comprehension: Reading Strategies for the Youngest Learners. Boston: Stenhouse Publishers.

Franzen, A. McGill, \& Allington, R. (ed) (2011). Handbook of Reading Disability Research. UK: Routledge.

Grellet, F. (1981). Developing Reading Skills. Cambridge: Cambridge University Press.

Griffin, C, C., Malone, L. D., \& Edward, J. K. (1995). Effects of Graphic Organizer Instruction on Fifth-Grade Students. The Journal of Educational Research, 89(2), 98-107.

Griffin, C. C., \& Tulbert, B. L. (1995). The Effects of Graphic Organizers on Students' Comprehension and Recall of Expository Text: A review of the Research and Implication of Practice. Reading and Writing Quarterly: Overcoming Learning Difficulties, 11(1). http://dx.doi.org/0.1080/1057356950110106.

Hibbard, K. M., \& Wagner, E. A. (2003). Assessing and Teaching Reading Comprehension and Writing K-3 (Vol. 2). New York: Eye on Education.

Horton, S. V., Lovitt, T. C., \& Bergerud, D. (1990). The Effectiveness of Graphic Organizers for Three Classifications of Secondary Students in Content Area Classes. Journal of Learning Disabilities, 23, 12-22.

Jiang, X., \& Grabe, W. (2007). Graphic Organizers in Reading Instruction: Research Findings and Issues. Reading in a Foreign Language, 19(1), 34-35.

Jiang, X. (2012). Effects of Discourse Structure Graphic Organizer on EFL Reading Comprehension. Reading in a Foreign Language, 24(1), 84-105.

Keene, E. O., \& Zimermann, S. (1997). Mosaic of Thought: Teaching Comprehension in a Reader's Workshop. New York: Heinemann.

Kim, A. H., Vaughn, S., Wanzek, J., \& Wei, S. (2004). Graphic Organizers and their Effects on the Reading Comprehension of Students with LD: A synthesis of Research. Journal of Learning Disabilities, 37(2), $105-118$.

Koda, K. (2007). Reading and language learning: Cross linguistic constraints on second language reading development. Language Learning, 57(1), 1-44. 
The three forms of water are solid, liquid and gas. Did you guess right? Solid water is frozen and known as ice. When water is boiled, or the sun heats the surface of a body of water, its molecules can absorb enough energy to evaporate into the air - that is, to become a gas called water vapor.

Up in Earth's atmosphere, water vapor cools and collects into clouds. When enough clusters of cloud particles stick together, they tumble back down to Earth as rain, snow, hail, or sleet. This process of water evaporating, condensing and falling to Earth is the water cycle.

Water on the Earth can flow above the ground in a stream or river. It can run underground, too. And water can also be frozen into large glaciers. Whichever form it is in, it can be a powerful force, changing the shape of the land as it erodes mountains and carves valleys.

We cannot survive on Earth without water-so we must all do our part to take care of it. People use the fresh water of lakes and rivers for drinking, washing, cooking and growing food.

Did you know that most of the world's population does not have direct access to clean water? We are very lucky to live in a country where clean water is "streaming" from our faucets. It is up to us to be responsible users of the water available on Earth.

\begin{tabular}{|c|c|c|}
\hline S.No & Question & Type of Reading Question \\
\hline 1 & $\begin{array}{l}\text { Which of the following is main idea of the passage? } \\
\text { a. Contamination of water } \\
\text { b. process of raining } \\
\text { c. All about water } \\
\text { d. Responsibility of man }\end{array}$ & \multirow[t]{2}{*}{ Identifying the main idea } \\
\hline 2 & Based on the main idea, suggest an apt title for the passage. & \\
\hline 3 & $\begin{array}{l}\text { "water has lot of useful minerals" } \\
\text { Identify two supporting details from the passage for the above idea. }\end{array}$ & \multirow{2}{*}{ finding the supporting details } \\
\hline 4 & $\begin{array}{l}\text { Identify a supporting detail from the passage which talks about the } \\
\text { conservation of water. }\end{array}$ & \\
\hline 5 & $\begin{array}{l}\text { Find synonymous word from the passage for the below words: } \\
\text { a. disappear } \\
\text { b. tap }\end{array}$ & \multirow{2}{*}{ understanding vocabulary } \\
\hline 6 & $\begin{array}{l}\text { Fill in the blanks with the appropriate words from the passage. } \\
\text { a. substance that provides nourishment essential for } \\
\text { growth and the maintenance of life. }\end{array}$ & \\
\hline 7 & $\begin{array}{l}\text { Identify the following sentences as fact or opinion: } \\
\text { 1. The process of water evaporating, condensing and falling to } \\
\text { Earth is called water cycle. }\end{array}$ & \multirow[t]{2}{*}{ distinguishing fact from opinion } \\
\hline 8 & $\begin{array}{l}\text { 2. Most of the world's population does not have direct access to } \\
\text { clean water }\end{array}$ & \\
\hline 9 & What happens if the water bodies are contaminated? & \multirow[b]{2}{*}{ making inferences } \\
\hline 10 & $\begin{array}{l}\text { What do you infer from the following extract? } \\
\text { Minerals and other nutrients enter the plant with the water. }\end{array}$ & \\
\hline
\end{tabular}

\section{Passage 2}

Category
Each day, your teeth are attacked by millions of bacteria. They form a clear coating on your teeth called plaque.
When you eat, they eat too, gobbling up sugar and making acids that burn holes in your teeth. You can taste the acid
that bacteria make about an hour after you have eaten something sweet. The acid tastes sour. The best way to prevent
plaque is to brush for two minutes at least two times a day using toothpaste and a toothbrush.
Your teeth have three main layers. Enamel covers the outside, dentin is in the middle, and pulp is on the inside.
Enamel only covers the part of your tooth that sticks out of your gums, called the "crown". The part below your gum
line is the "root".
Enamel is the hardest material in your body, and that's a good thing considering what you eat. Chewing food is a
tough job, so your teeth must have enamel to protect them. Dentin makes up most of your tooth. It is also hard and
bony, but not as hard as enamel. It protects the nerves and blood vessels in your tooth's pulp.
When bacteria eat through the enamel on your teeth, they form cavities. Cavities are bad, because they give bacteria
a place to hide. Inside of the cavity, bacteria will continue to eat and to make acid that burns its way even deeper into


your teeth. If a cavity gets deep enough into your tooth, it will begin to hurt because the nerves in your tooth pulp will be exposed.

Dentists can fix most cavities, but it is not an easy process. First, they drill away the rotten part of your tooth. Then they can fill the hole left behind. The ceramic material used to fill the hole is your tooth is like glass: it is hard like your enamel, but it can break easily. So, it is best to avoid cavities when you can.

Most toothpaste has fluoride, a chemical that hardens your tooth enamel. Your drinking water may also have fluoride in it. Using fluoride helps to prevent cavities by making it harder for acids to burn through your teeth.

Preventing cavities by brushing for two minutes at least twice a day with toothpaste and a toothbrush is a good way to make sure that you will still have your teeth when you are older. It will also give you something to smile about.

\begin{tabular}{|c|c|c|}
\hline S.No & Question & Type of Reading Question \\
\hline 1 & $\begin{array}{l}\text { Which of the following is main idea of the passage? } \\
\text { a. strength of the enamel } \\
\text { b. Dentists and the teeth } \\
\text { c. Teeth and the damage caused to it } \\
\text { d. Avoid cavity }\end{array}$ & \multirow[t]{2}{*}{ Identifying the main idea } \\
\hline 2 & Based on the main idea, suggest an apt title for the passage. & \\
\hline 3 & $\begin{array}{l}\text { When bacteria eat through the enamel on your teeth, they form cavities. } \\
\text { Read the above sentence from the passage and identify which of the } \\
\text { following is not a supporting: } \\
\text { a. Bacteria can survive only when there are enough cavities. } \\
\text { b. The enamel of your teeth should be cleaned and maintained to avoid } \\
\text { cavity. } \\
\text { c. If the cavity is deep enough till the pulp, you will have to suffer pain. } \\
\text { d. Regular and proper brushing of teeth will help in fighting cavity. }\end{array}$ & \multirow[t]{2}{*}{ finding the supporting details } \\
\hline 4 & $\begin{array}{l}\text { Identify a supporting detail from the passage which talks about the } \\
\text { prevention of the deposition of bacteria on the teeth. }\end{array}$ & \\
\hline 5 & $\begin{array}{l}\text { Find synonymous word from the passage for the below words: } \\
\text { a. defend } \\
\text { b. avert }\end{array}$ & \multirow{2}{*}{ understanding vocabulary } \\
\hline 6 & $\begin{array}{l}\text { Fill in the blanks with the appropriate words from the passage. } \\
\text { is an important part of the teeth. It is covered by the enamel } \\
\text { and it covers the pulp. }\end{array}$ & \\
\hline 7 & $\begin{array}{l}\text { Identify the following sentences as fact or opinion: } \\
\text { 1. Bacteria make a clear coating on the teeth called plaque. }\end{array}$ & \multirow{2}{*}{$\begin{array}{l}\text { distinguishing fact from } \\
\text { opinion }\end{array}$} \\
\hline 8 & $\begin{array}{l}\text { 2. The best way to prevent plaque is to brush for two minutes at least two } \\
\text { times a day using toothpaste and a toothbrush. }\end{array}$ & \\
\hline 9 & $\begin{array}{l}\text { Enamel is the hardest material in your body, and that's a good thing } \\
\text { considering what you eat. } \\
\text { What is the author implying? } \\
\text { a. nothing can destroy enamel } \\
\text { b. enamel is very hard because you a lot } \\
\text { c. enamel helps you to chew the food you eat easily } \\
\text { d. enamel is the hardest material, but it is good for eating. }\end{array}$ & \multirow[t]{2}{*}{ making inferences } \\
\hline 10 & $\begin{array}{l}\text { It will also give you something to smile about. } \\
\text { What does 'it' signify in the above extract from the passage? }\end{array}$ & \\
\hline
\end{tabular}

